\title{
Metode Pendekatan Keluarga, Terobosan Baru dalam Pembangunan Kesehatan di Indonesia
}

\author{
Decky Ferdiansyah \\ Badan Perenc anaan Pembangunan Daerah (Bappeda) Provinsi Lampung, Indonesia \\ Terbit online : 17 November 2016
}

\section{Abstrak :}

Dalam memperingati HKN ke 52 Tahun 2016 ini Kemenkes RI telah menetapkan tema "Masyarakat Hidup Sehat, Indonesia Kuat". Tema ini dipilih sebagai wujud dari Program Indonesia Sehat dengan Pendekatan Keluarga. Banyak negara menerapkan konsep pelayanan kesehatan dasar atau dikenal dikenal dengan istilah primary health care. Di Indonesia menerapkan pelayanan kesehatan perorangan dan pelayanan kesehatan masyarakat dalam satu wadah terpadu yang dikenal sebagai pusat kesehatan masyarakat (puskesmas). Pendekatan keluarga adalah pendekatan pelayanan puskesmas yang menggabungkan upaya kesehatan perorangan (UKP) dan upaya kesehatan masyarakat (UKM) tingkat pertama secara berkesinambungan dengan didasarkan kepada data dan informasi dari profil kesehatan keluarga. Terobosan baru dalam pembangunan kesehatan berupa pendekatan keluarga ini memerlukan dukungan dari berbagai pihak.

Keyword : pendekatan keluarga, puskesmas

\section{Pendahuluan}

Setiap tanggal 12 November selalu diperingati sebagai Hari Kesehatan Nasional (HKN). Peringatan HKN selalu disi dengan berbagai kegiatan dan kampanye kesehatan dari jajaran Kementerian Kesehatan RI (Kemenkes RI), Dinas Kesehatan Provinsi dan Dinas Kesehatan Kabupaten/Kota seluruh Indonesia. Berbagai kegiatan digelar untuk mengkampanyekan pesanpesan kesehatan kepada masyarakat.

Dalam memperingati HKN ke 52 Tahun 2016 ini Kemenkes RI telah menetapkan tema "Masyarakat Hidup Sehat, Indonesia Kuat". Tema ini dipilh sebagai wujud dari Program Indonesia Sehat dengan Pendekatan Keluarga.

"Program Indonesia Sehat dengan Pendekatan Keluarga" adalah salah satu terobosan yang ditetapkan Kemenkes RI dalam upaya meningkatkan keberhasilan pembangunan kesehatan. Program ini merupakan program utama dalam pembangunan kesehatan yang sasarannya telah tertuang dalam Rencana Pembangunan Jangka Menengah Nasional (RPJMN) 2015-2019.

\section{Konsep Pelayanan Kesehatan Dasar di Negara Maju}

Banyak negara menerapkan konsep pelayanan kesehatan dasar atau dikenal dikenal dengan istilah primary health care. Implementasi dari primary health care ini umumnya berbeda-beda di tiap negara. Di beberapa negara maju, primary health care diterapkan dengan memisahkan pelayanan perorangan/individu dengan pelayanan kesehatan masyarakat. 
Pelayanan kesehatan masyarakat dilaksanakan oleh petugas dan sarana kesehatan milik publik yang didirikan khusus untuk itu, baik pemerintah ataupun swasta. Sedangkan pelayanan kesehatan perorangan dilaksanakan oleh dokter keluarga.

Di negara-negara maju, seorang dokter keluarga harus memiliki kompetensi khusus yang lebih baik dibandingkan seorang dokter umum biasa. Ada pendidikan tambahan yang harus dijalani oleh dokter umum untuk menjadi dokter keluarga. Kompetensi khusus ini yang diharapkan mampu menjadikan seorang dokter keluarga dapat memberikan pelayanan kesehatan secara lebih menyeluruh dan berkesinambungan kepada suatu individu ataupun kumpulan individu seperti keluarga. Pendekatan dokter keluarga sebagai primary health care merupakan suatu solusi dalam mewujudkan kualitas kesehatan individu dan masyarakat yanglebih baik.

\section{Konsep Pelayanan Kesehatan Dasar di Indonesia}

Berbeda dengan hal tersebut, di Indonesia menerapkan pelayanan kesehatan perorangan dan pelayanan kesehatan masyarakat dalam satu wadah terpadu yang dikenal sebagai pusat kesehatan masyarakat (puskesmas). Sehingga puskesmas menjalankan kedua pelayanan tersebut secara bersamaan.

Upaya kesehatan yang ada di puskesmas mencakup upaya kuratif, rehabilitatif, preventif dan promotif. Dalam perkembangannya, Fungsi pelayanan kesehatan perorangan dan masyarakat yang dilakukan oleh puskesmas berupa tindakan kuratif (pengobatan) menjadi lebih dominan dibandingkan kegiatan-kegiatan promotifdan preventif.

Masyarakat menganggap bahwa tidak perlu datang ke puskesmas kalau tidak sakit. Disisi lain, petugas puskesmas menganggap bahwa kalau tidak ada yang datang ke puskesmas, maka masyarakat sudah sehat. Sehingga ada anggapan bahwa puskesmas identik dengan tempat berkumpulnya orang-orang sakit. Anggapan seperti ini harus dapat diubah dengan program pendekatan keluarga.

\section{Program Kesehatan dengan Pendekatan Keluarga}

Keluarga adalah suatu lembaga yang menupakan satuan terkecil dari masyarakat. Karena merupakan satuan dari masyarakat, keluarga memiliki peran yang cukup signifikan dalam menentukan derajat kesehatan masyarakat. Tinggi rendahnya derajat kesehatan keluarga akan sangat menentukan tinggi rendahnya derajat kesehatan masyarakat.

Sangat tepat Kementerian Kesehatan RI dalam menetapkan pendekatan keluarga untuk mencapai keberhasilan pembangunan kesehatan. Pendekatan keluarga sebagai satuan terkecil masyarakat dinilai akan lebih efektif dalam mengatasi berbagai persoalan kesehatan seperti gizi buruk, sanitasi buruk, penyebaran penyakit menular sepert tuberkolusis, HIVIAIDS, malaria serta pengendalian penyakit tidak menular seperti obesitas, darah tinggi, diabetes dan lain-lain.

Sesuai amanat UU No. 23 Tahun 2014 tentang Pemerintahan Daerah, pembangunan keluarga adalah upaya mewujudkan keluarga berkualitas yang hidup dalam lingkungan yang sehat Menurut Friedman (1998), terdapat lima fungsi keluarga yang salah satunya adalah fungsi perawatan atau pemeliharaan kesehatan (The Health Care Function). Fungsi ini adalah untuk mempertahankan keadaan kesehatan anggota keluarga agar tetap memiliki produktivitas yang tinggi. Fungsi ini dikembangkan menjadi tugas keluarga di bidang kesehatan. Setiap anggota keluarga memiliki peran dan fungsinya masing-masing untuk mempertahankan kondsi kesehatan di dalam keluarga. Kondisi kesehatan yang dipertahankan mencakup pencegahan, perawatan, pemeliharaan, termasuk upaya membangun hubungan timbal balik antara keluarga dengan fasilitas kesehatan. 


\section{Puskesmas sebagai Penentu Keberhasilan Program Pendekatan Keluarga}

Dengan diterbitkannya Peraturan Menteri Kesehatan (Permenkes) RI No. 39 Tahun 2016 tentang "Pedoman Penyelenggaraan Program Indonesia Sehat dengan Pendekatan Keluarga", pemerintah telah menetapkan bahwa pelaksana dan program ini adalah pusat kesehatan masyarakat (puskesmas). Puskesmaslah ujung tombak dan penentu keberhasilan program ini. Adapun area prioritas/sasaran yang telah ditetapkan oleh pemerintah melalui program ini adalah penurunan angka kematian ibu/angka kematian bayi (AKI dan AKB), penurunan prevalensi balita pendek (stunting), penanggulangan penyakit menular dan penanggulangan penyakit tidak menular. Pelaksanaannya melalui pendekatan upaya promotif dan preventif tanpa mengabaikan upaya kuratif dan rehabilitatif.

Pendekatan keluarga adalah pendekatan pelayanan puskesmas yang menggabungkan upaya kesehatan perorangan (UKP) dan upaya kesehatan masyarakat (UKM) tingkat pertama secara berkesinambungan dengan didasarkan kepada data dan informasi dari profil kesehatan keluarga. Kedepan, puskesmas sebagai ujung tombak dari pelayanan kesehatan milik pemerintah hanus lebih proaktif lagi dalam melaksanakan program-program kesehatannya. Program preventif dan promotif harus kembali digalakkan.

Melalui pendekatan keluarga, diharapkan puskesmas dapat menangani masalah-masalah kesehatan individu secara siklus hidup (life cycle). Ini artinya penanganan masalah kesehatan dilakukan sejak fase dalam kandungan, proses kelahiran, tumbuh kembang masa bayi-balita, usia sekolah dasar, remaja, dewasa sampai usia lanjut. Fokusnya adalah pada kesehatan individu-individu dalam keluarga. Hal ini sesuai dengan Rencana Strategis Kementerian Kesehatan RI Tahun 2015 - 2019 dimana penerapan pelayanan kesehatan harus terintegrasi dan berkesinambungan (continuum of care).

\section{Contoh Kegiatan Program Pendekatan Keluarga}

Salah satu bentuk dari pendekatan keluarga yang dapat dilakukan oleh puskesmas adalah melalui kegiatan kunjungan rumah secara rutin dan terjadwal. Dengan kunjungan rumah, puskesmas dapat memperoleh data profil kesehatan keluarga (prokesga) yang berguna untuk mengenali secara lebih menyeluruh (holistic) masalah-masalah kesehatan di keluarga. Selain itu, kegiatan promotif dan preventif terhadap keluarga juga dapat terlaksana dengan kunjungan rumah.

Kombinasi dari profil kesehatan keluarga dan upaya promotif-preventif tentu akan lebih efektif dalam mengatasi masalah-masalah kesehatan di keluarga. Program pendekatan keluarga yang dilaksanakan puskesmas juga secara langsung akan menguatkan manajemen puskesmas secara internal, yang mencakup sumber daya manusia, pendanaan, sarana prasarana, program kesehatan, sistem informasi dan jejaring dengan pihak terkait di lingkup wilayah kerjanya seperti puskesmas pembantu (pustu), puskesmas keliling (pusling), pos pelayanan terpadu (posyandu), bidan desa dan lain-lain.

\section{Hal yang Mempengaruhi Keberhasilan Program Pendekatan Keluarga}

Keberhasilan program ini tentunya memerlukan pemahaman dan komitmen yang sungguhsungguh, sistematis dan terencana dari seluruh petugas puskesmas. Kesamaan pemahaman dan komitmen yang kuat akan menghasilkan tercapainya target area prioritas/sasaran dari program ini. Komitmen untuk bekerja di dalam dan di luar gedung puskesmas tentu juga perlu didukung oleh Dinas Kesehatan (Dinkes) Kabupaten/Kota sebagai induk dari puskesmas. 
Salah satu bentuk dukungan dari Dinkes adalah melalui alokasi anggaran berupa dana operasional puskesmas. Walaupun puskesmas sudah memiliki dana kapitasi dari BPJS Kesehatan yang dapat digunakan untuk pelaksanaan program ini, dukungan abkasi anggaran dari Dinkes tentu juga diharapkan tetap didapatkan. Terlebh kegiatan kunjungan rumah yang memerlukan pengorbanan ekstra dari petugas puskesmas. Kunjungan rumah yang dilakukan harus mempertimbangkan jumlah petugas puskesmas, jumlah keluarga di wilayah kerja puskesmas, kondisi geografis dan juga pendanaan.

Bila diperlukan, puskesmas dapat merekrut petugas tambahan dari kader-kader kesehatan di wilayah kerjanya. Rekrutmen ini tentu merupakan hasil analisis kebutuhan dengan mempertimbangkan hal-hal tersebut di atas. Kunjungan rumah yang dilakukan juga dapat menjadi sarana penyampaian pesan-pesan kesehatan kepada individu-individu dalam keluarga. Maka petugas dapat memberikan leaflet/flyer tentang keluarga berencana, pemeriksaan kehamilan, asi eksklusif, imunisasi, gizi seimbang, pencegahan penyakit menular, pencegahan penyakit tidak menular, bahaya merokok, cara mencuci tangan yang baik, jaminan kesehatan nasional dan lain-lain.

Profil kesehatan keluarga (prokesga) yang dibawa pada saat kunjungan rumah mengacu pada indikator keluarga sehat yang telah ditetapkan Kementerian Kesehatan RI. Hal ini untuk menyeragamkan pendataan agar efektif dan tepat sasaran. Data prokesga didapat dari kunjungan rumah merupakan data yang sangat berharga bagi puskesmas. Analisis yang akurat terhadap prokesga akan berguna untuk mengidentifikas dan menetapkan intervensi kesehatan apa saja yang dibutuhkan terhadap suatu keluarga. Setiap keluarga tentu akan menghasilkan intervensi kesehatan yang berbeda dengan keluarga lain. Perbedaan ini akan dapat dibaca sebagai hasil yang akurat dengan adanya keseragaman indikator. Sehingga hasil akhir yang diharapkan adalah tercapainya area prioritas/sasaran dari program ini.

\section{Kesimpulan}

Sekali lagi, terobosan baru dalam pembangunan kesehatan berupa pendekatan keluarga ini memerlukan dukungan dari berbagai pihak. Sampa kapan Indonesia harus terus menerus berkutat dengan persoalan-persoalan kesehatan yang mendasar seperti tingginya angka kematian ibu/angka kematian bayi, gizi buruk, penyebaran penyakit menular dan tidak menular? Maka pertanyaan tersebut mungkin mampu dijawab dengan keberhasilan "Program Indonesia Sehat dengan Pendekatan Keluarga".

Referensi:

1. Republik Indonesia, 2014 Undang-Undang tentang Pemerintahan Daerah, Jakarta : Sekretariat Negara

2. Republik Indonesia, 2015 Peraturan Presiden tentang Rencana Pembangunan Jangka Menengah Nasional Tahun 2015-2019, Jakarta : Sekretariat Negara

3. Republik Indonesia, 2016 Peraturan Menteri Kesehatan tentang Pedoman Penyelenggaraan Program Indonesia Sehat dengan Pendekatan Keluarga, Jakarta : Kementerian Kesehatan

4. Friedman, M.R., 1998 Family Nursing : Research, Theory and Practice, Pearson (1665)

Artikel ini terbit online di http://farmasetika.com/2016/11/17/metode-pendekatan-keluarga-terobosanbaru-dalam-pembangunan-kesehatan-di-indonesia/ 